\title{
The effect of habitually large protein intake on renal function of strength athletes: an update
}

\author{
Lonnie M Lowery ${ }^{1,2^{*}}$, Allison Daugherty ${ }^{3}$, Brian Miller ${ }^{4}$, Sarah Dye ${ }^{1}$, Loren Liming ${ }^{1}$ \\ From International Society of Sports Nutrition: 8th Annual ISSN Conference and Expo \\ Las Vegas, NV, USA. 24-25 June 2011
}

\begin{abstract}
Background
A quasi-experimental study was performed to evaluate the renal effects of large, chronic protein intakes among strength athletes. Population-specific data are still lacking regarding this cohort of athletes who commonly seek additional protein for performance and body composition purposes.
\end{abstract}

\section{Methods}

In a design involving self-report, estimated and direct measures, urinary variables of renal function (extrapolated morning fasted-and actual 12-hour creatinine clearance) were assessed via a DCA 2000 urinalysis analyzer (Bayer healthcare, LLC, Elkhart, IN) in Caucasian male strength trainers $(\mathrm{N}=17)$ who do $(\mathrm{PROT})$ and do not (CTRL) seek ample protein intake via foods and supplements. Use of fasted urinary $\mathrm{Cr}$ values in some creatinine clearance $(\mathrm{CrCl})$ expressions allowed for comparisons beyond spot measures, without interference of daytime meals and mild activities. $\mathrm{CrCl}$ was derived as follows: $U_{\mathrm{Cr}} \times U_{\mathrm{vol}} / \mathrm{P}_{\mathrm{Cr}} \times$ min. where $\mathrm{U}=$ urinary and $\mathrm{P}=$ plasma. Direct plasma variables (i.e. a standard "renal panel") were also measured via commercial techniques (LabCare Plus, Barberton, $\mathrm{OH}$ ) and compared. Body mass and composition were also assessed via balance scale and dual $\mathrm{x}$-ray absorptiometry (DEXA). All participants abstained from exercise for three days prior to testing.

\section{Results}

Over a reported $9.1+/-6.5$ year period, chronic protein intakes (mean+/-SD: PROT $2.5+/-0.83 \mathrm{~g} / \mathrm{kg}$, CTRL 1.27 $+/-0.33 \mathrm{~g} / \mathrm{kg}$ ), were greater in the protein seeking group

\footnotetext{
* Correspondence: LLowery@winona.edu

'Health, Exercise and Rehabilitation Sciences, Winona State University, 362 Maxwell Hall, Winona, MN 55987, USA

Full list of author information is available at the end of the article
}

$(\mathrm{p}<0.05)$ as verified by diet logs. Concomitant with significantly greater 12-hour urine output (PROT 1811 +/-896 ml vs. CTRL $1162+/-447 \mathrm{ml}$ ), no statistically significant effects were detected in creatinine clearance extrapolated from fasting urinary $\mathrm{Cr}$ values (PROT $255.0+/-147.9 \mathrm{ml} / \mathrm{min}^{*} 1.73 \mathrm{~m}^{2}$ vs. CTRL $196.5+/-50.6$ $\mathrm{ml} / \mathrm{min} / 1.73 \mathrm{~m}^{2}$ )or from actual 12-hour creatinine clearance (PROT $166.0+/-59.1 \mathrm{ml} / \mathrm{min}^{*} 1.73 \mathrm{~m}^{2}$ vs. CTRL $\left.160.2+/-38.5 \mathrm{ml} / \mathrm{min} / \mathrm{m}^{2}\right)$. Similarly, no differences were observed among serum variables including creatinine, $\mathrm{BUN}$ :Cr ratio, sodium, potassium, chloride, anion gap, calcium, albumin, or phosphorus. There was a trend toward higher BUN in PROT $(8.8+/-1.3 \mathrm{mg} / \mathrm{dl} \mathrm{vs}$. CTRL $8.4+/-1.8 \mathrm{mg} / \mathrm{dl}$ ) but this disappeared when normalizing for serum creatinine. Groups did not differ in age but did differ in body mass (PROT $98.3+/-16.8 \mathrm{~kg}$ vs. CTRL $83.3+/-7.0 \mathrm{~kg} ; \mathrm{p}<0.05)$ and fat free mass (PROT $79.0+/-9.9 \mathrm{~kg}$ vs. CTRL $68.9+/-6.7 \mathrm{~kg}$; $\mathrm{p}<$ 0.05).

\section{Conclusion}

It is concluded that, within the limitations of this research design, a multi-year intake of ample protein among male Caucasian strength athletes does not affect common markers of renal function. Future research should focus on long periods of high protein intake using true experimental designs, specific protein types, more sensitive renal function techniques such as inulin clearance, and any potential differences between protein foods versus supplements.

\section{Acknowledgements \\ The authors would like to thank Dr. Troy Smurawa, University of Akron Health Services for his assistance with the serum variables and Director Kathryn Watkins-Wendell of the University of Akron Office of Research Services for her support of this student-faculty research.}




\section{Author details}

${ }^{1}$ Health, Exercise and Rehabilitation Sciences, Winona State University, 362

Maxwell Hall, Winona, MN 55987, USA. ${ }^{2}$ Nutrition, Exercise and Wellness

Associates, LLC, Cuyahoga Falls, OH 44223, USA. ${ }^{3}$ Food Science and Human

Nutrition, University of Maine, Orono, ME, USA. ${ }^{4}$ The University of Akron

Nutrition Center student volunteer, Akron, OH, USA.

Published: 7 November 2011

doi:10.1186/1550-2783-8-S1-P33

Cite this article as: Lowery et al:: The effect of habitually large protein

intake on renal function of strength athletes: an update. Journal of the

International Society of Sports Nutrition 2011 8(Suppl 1):P33.

Submit your next manuscript to BioMed Central and take full advantage of:

- Convenient online submission

- Thorough peer review

- No space constraints or color figure charges

- Immediate publication on acceptance

- Inclusion in PubMed, CAS, Scopus and Google Scholar

- Research which is freely available for redistribution

Submit your manuscript at www.biomedcentral.com/submit 